\title{
Treatment of intoxication with combinations of drugs and management of the associated shock
}

\author{
J. A. Graham \\ F.R. C.S.(Glasg.), F.R.C.S., M.B., M.Sc. \\ Registrar in Surgery \\ R. I. GLeadle \\ M.B., M.R.C.P. \\ Senior Registrar in Medicine
}

\author{
I. MCA. LEDINGHAM \\ M.B.
}

Senior Lecturer in Surgery

A. L. Linton

M.B., F.R.C.P.E., F.R.C.P.G.

Consultant Physician in Renal Diseases

The Intensive Therapy Unit and the Renal Unit, Western Infirmary, Glasgow, W.1

SELF-POISONING with combinations of drugs is becoming increasingly common and such cases present considerable therapeutic problems.

The difficulty in measuring blood and urine levels of many new sedatives and tranquillizers has meant that no firm guide-lines for treatment have been laid down; in particular, little evidence exists as to the value of measures such as forced diuresis and haemodialysis in increasing the rate of removal of the drugs from the body. In addition, precise details of the multiple drugs ingested are seldom available, and treatment often resolves itself into the application of good respiratory care and the correction of shock. This latter problem is often difficult, and persistent hypotension commonly contributes to the patient's death. The present case is reported because of the success of the therapeutic methods used, and the initial failure of forced diuresis.

\section{Case report}

A female aged 27 was found unconscious and admitted to hospital at 11.00 hours on 18 September 1968. Comprehensive enquiry suggested that she had taken phenobarbitone and other drugs, including chlordiazepoxide and phenelzine.

On admission she was deeply unconscious, totally areflexic and had fixed, dilated pupils. Respiration was clinically adequate and systolic blood pressure $105 \mathrm{mmHg}$. Serum barbiturate level was reported as $9 \mathrm{mg} / 100 \mathrm{ml}$ and on the basis of percentage hydrolysis the barbiturate was said to be of the long-acting group (Broughton, 1956). This apparently confirmed the suggestion that the patient had taken phenobarbitone, and that the barbiturate was not a major factor in the intoxication; a diagnosis of mixed sedative-tranquillizer intoxication was made. This conclusion was later found to be an error, for there is now no reasonable doubt that the barbiturate ingested was amylobarbitone, both on the evidence of the patient and subsequent identification of the drug in the blood by thin-layer chromatography. The patient had also taken large amounts of chlordiazepoxide and phenelzine.

On the erroneous assumption that phenobarbitone had been the drug ingested, forced diuresis was begun as described by Linton et al. (1964), with the object of maintaining the circulation and removing at least the barbiturate component of the intoxication. Serum urea and electrolytes were normal, and there was no clinical evidence of pre-existing cardiac or renal disease. At 14.00 hours ( $3 \mathrm{hr}$ after admission), increasing respiratory depression necessitated transfer of the patient to the Intensive Therapy Unit; systolic blood pressure had fallen to $70 \mathrm{mmHg}$ and blood gases were: $\mathrm{Po}_{2} 54 \mathrm{mmHg}, \mathrm{PCO}_{2} 80 \mathrm{mmHg}$, pH $7 \cdot 2$ (spontaneous respiration, on air).

An endotracheal tube was passed and assisted ventilation was begun using a Cape ventilator. Breathing $100 \%$ oxygen with a minute volume of 9.5 litres, blood gases (corrected for temperature) were: $\mathrm{PO}_{2} 405 \mathrm{mmHg}, \mathrm{PCO}_{2} 26.5 \mathrm{mmHg}$ and $\mathrm{pH}$ 7.61 , with a base deficit of $6 \mathrm{mEq}$. Systolic blood pressure remained $70 \mathrm{mmHg}$ and progressive fall in rectal temperature to $34^{\circ} \mathrm{C}$ necessitated re-warming with a heat cage. The rectal temperature reached $37^{\circ} \mathrm{C}$ at 23.00 hours on the day of admission.

By 19.00 hours on 19 September 1968 the patient had received $3500 \mathrm{ml}$ of fluid intravenously, but urine volume was only $1450 \mathrm{ml}$ despite the administration of $80 \mathrm{mg}$ of frusemide and $10 \mathrm{~g}$ of mannitol. Since there were no clinical signs of overhydration, it was thought that the relative failure of diuresis might be due to pre-existing dehydration. In addition, the hypotension of barbiturate intoxication has been attributed to a relative hypovolaemia from venous pooling of blood (Shubin \& Weil, 1965), so it was 
decided to give $1000 \mathrm{ml}$ of plasma and to continue with the forced diuresis in an attempt to raise the falling blood pressure. Over the next $8 \mathrm{hr}$, however, blood pressure became unrecordable by standard methods, and a further $160 \mathrm{mg}$ of frusemide given intravenously produced only a small increase in urine flow rate. At 09.00 hours on 19 September 1968, $22 \mathrm{hr}$ after admission, the patient was still deeply comatose with fixed, dilated pupils, the extremities were cold and the skin was pale, but there was no cyanosis. Direct recording of the arterial pressure using a transducer and ink-jet recorder (ElenaSchönander 'Minograf 34') showed the blood pressure to be $50 / 30$, mean $35 \mathrm{mmHg}$, although no pulses could be felt nor any blood pressure recorded by sphygmomanometer. Intermittent positive-pressure ventilation continued with apparently good air entry to both lungs; the blood gases were: $\mathrm{Po}_{2}$ $110 \mathrm{mmHg}, \mathrm{PCO}_{2} 32 \mathrm{mmHg}$ and $\mathrm{pH} \mathrm{7 \cdot 48}$. Standard bicarbonate was $25 \mathrm{mEq} / 1$ and base excess $1.8 \mathrm{mEq}$. The deterioration in $\mathrm{Po}_{2}$ was thought to be due to venous admixture effect consequent upon hypotension and pulmonary oedema; the presence of pulmonary oedema was confirmed on chest X-ray. Serum barbiturate level was $9.8 \mathrm{mg} / 100 \mathrm{ml}$ and central venous pressure recordings started at this time indicated a level of $24 \mathrm{~cm} \mathrm{H}_{2} \mathrm{O}$. It was, therefore, obvious that forced diuresis had failed, and the patient now had considerable fluid overload. There was doubt whether vasopressor drugs would be of any value in view of the existing peripheral vasoconstriction; Shubin \& Weil (1965) showed that the effect of such drugs in this situation may be to reduce urinary output and prevent satisfactory expansion in plasma volume, although the effect on cardiac output and peripheral vascular resistance appeared to vary with the dose of drug used. Equally, it was feared that attempts to improve tissue perfusion with a vasodilator drug would be likely to cause a further and probably fatal fall in blood pressure. A single dose of $100 \mathrm{mg}$ of hydrocortisone was given to assess the effect of steroids, but at 11.30 hours the blood pressure had fallen to $45 / 25$, mean $30 \mathrm{mmHg}$.

It was, therefore, decided to try the effect of mephentermine, and the patient was given $45 \mathrm{mg}$ of this drug by slow intravenous injection. This immediately improved the mean blood pressure to $50 \mathrm{mmHg}$ and increased urine flow rate from an average $75 \mathrm{ml} / \mathrm{hr}$ to $350 \mathrm{ml}$ in the next hour. A continuous infusion of mephentermine was begun (150 $\mathrm{mg}$ in $500 \mathrm{ml}$ of $5 \%$ dextrose), and given at a rate varying between 0.45 and $0.66 \mathrm{mg}$ mephentermine/min; this maintained the mean blood pressure around $50 \mathrm{mmHg}$. Despite the fears that mephentermine would further reduce cardiac output and tissue perfusion, the increase in pressure was associated with a continued improvement in urine flow rate, this remaining around $250 \mathrm{ml} / \mathrm{hr}$. The skin of the extremities also became noticeably pinker and warmer.

This regime was continued until 09.30 hours on 20 September 1968 (46 hr after admission). It now proved possible further to increase urine flow rate with frusemide (total of $560 \mathrm{mg}$ given in $8 \mathrm{hr}$ ), and during the 24-hr period after the start of mephentermine therapy, some 5 litres of the retained fluid were excreted $(2000 \mathrm{ml}$ in, $7000 \mathrm{ml}$ out $)$. Fluid intake and output since admission were now almost equal, and the central venous pressure had fallen to $13.5 \mathrm{~cm}$ $\mathrm{H}_{2} \mathrm{O}$. Serum barbiturate level was $6.5 \mathrm{mg} / 100 \mathrm{ml}$. Blood pressure was $75 / 40$, mean $53 \mathrm{mmHg}$ and gradual reduction in rate of mephentermine infusion was possible. The infusion was stopped at 14.00 hours on 20 September 1968, and there was no subsequent fall in blood pressure. During the next $18 \mathrm{hr}$, the patient's condition improved steadily; blood pressure rose, and pupillary and cough reflexes returned. By 09.00 hours on 21 September 1968 (70 hr after admission) blood pressure was $117 / 62$, mean $85 \mathrm{mmHg}$. Spontaneous ventilation was resumed and the endotracheal tube was removed later in the day. The patient was fully conscious on the morning of 22 September 1968, and suffered no ill-effects from her $90-\mathrm{hr}$ period of unconsciousness other than a mild chest infection which responded quickly to antibiotics. There was no evidence of residual brain damage on clinical examination or on psychiatric assessment by a psychiatrist who had known her previously. Serum electrolytes and blood gas values were normal on 23 September 1968, and on 25 September 1968 she was transferred for psychiatric treatment.

\section{Discussion}

The drugs ingested by the patient described above were phenelzine, chlordiazepoxide and amylobarbitone. Pure phenelzine overdosage gives symptoms of massive catecholamine release (Solberg, 1961), which probably caused the widely dilated pupils and may have contributed to the peripheral vasoconstriction in this case. Chlordiazepoxide has been ingested in large doses without severe symptoms (Jenner \& Parkin, 1961); deaths have occurred but only when the drug was taken together with other depressive agents (Cruz, Cramer \& Parish, 1967). In retrospect, therefore, the amylobarbitone ingested was the major problem and the patient should probably have been treated by haemodialysis on the basis of our own previous criteria (Linton et al., 1967b). Failure to institute haemodialysis was due to the erroneous clinical and biochemical information suggesting that the barbiturate ingested had been phenobarbitone. Further studies on the 
identification of barbiturates as long or intermediateacting suggest that percentage hydrolysis is unsatisfactory for differentiation, and where clinical decisions hinge on the result thin-layer chromatography should be used.

Extensive previous experience with forced diuresis in barbiturate intoxication has demonstrated its safety and effectiveness (Strickler, 1966; Linton, Luke \& Briggs, 1967a). In this case, however, a second error of management was made in assuming that the failure to induce a diuresis quickly was due to pre-existing dehydration. It is probable that the low urine flow was due to poor renal perfusion with consequent low glomerular filtration rate. The resultant fluid overload should have been detected sooner by recording the central venous pressure earlier. It should, however, be emphasized that this is the first occasion in the experience of one of us (A.L.L.) in over 150 patients treated with forced diuresis that significant overhydration has occurred.

The principal therapeutic problem posed by this patient was the severe hypotension; no blood pressure or pulse were detectable by standard clinical methods for over $24 \mathrm{hr}$. The administration of fluids as suggested by Shubin \& Weil (1965) failed to raise the blood pressure. The potential danger of treating shock with vasopressor agents is well documented (Lancet, 1967) and their use in hypovolaemic states with failure of the vasoconstrictor mechanisms is illogical (Bloch et al., 1966). In order to improve tissue perfusion Lillehei et al. (1964) suggest the use of vasodilator drugs with replacement of blood volume as required. However, for the reasons already described, the patient was given mephentermine, with immediate effect on blood pressure, skin colour, temperature and urine volume. It seems probable that in hypotension of this severity mephentermine is beneficial by reason of its inotropic effect on the heart (Winsor, 1959; Li, Shimosato \& Etsten, 1962) with a resultant increase in cardiac output; there was no increase in heart rate in this case. A paradoxical reduction in peripheral vascular resistance, as seen here, has been noted in severe hypotension with other vasoconstrictor agents, notably metaraminol and noradrenaline (Shubin \& Weil, 1965). There is, however, no exact understanding of the mechanism of action, or indeed of the effect of vaso-active drugs under these conditions. Only by more frequent and intensive monitoring of haemodynamic changes in poison patients will empiricism be replaced by more logical therapy.

\section{References}

Bloch, J.H., Dietzman, R.H., Pierce, C.H. \& Lillehei, R.C. (1966) Theories of the production of shock. A review of their relevance to clinical practice. Brit. J. Anaesth. 38, 234.

Broughton, P.M.G. (1956) A rapid ultra violet spectrophotometric method for the detection, estimation and identification of barbiturates in biological materials. Biochem. J. 63, 207.

Cruz, I.A., Cramer, N.C. \& Parrish, A.E. (1968) Haemodialysis in chlordiazepoxide toxicity. J. Amer. med. Ass. 202, 438 .

Jenner, F.A. \& Parkin, D. (1961) A large overdose of chloridazepoxide. Lancet, ii, 322.

Lancet (1967) Annotation: vasopressor drugs. i, 830.

LI, T.H., Shimosato, S. \& EtSTen, B.E. (1962) Hemodynamics of mephentermine in man. New Engl. J. Med. 267, 180.

Lillehei, R.C., Longerbeam, J.K., Bloch, J.H. \& ManaX, W.G. (1964) The nature of irreversible shock: experimental and clinical observations. Ann. Surg. 160, 682.

Linton, A.L., Luke, R.G., Speirs, I. \& Kennedy, A.C. (1964) Forced diuresis and haemodialysis in severe barbiturate intoxication. Lancet, i, 1008.

Linton, A.L., LUKE, R.G. \& BRIGGS, J.D. (1967a) Methods of forced diuresis and its application in barbiturate poisoning. Lancet, ii, 377.

Linton, A.L., Luke, R.G., Briggs, J.D. \& Kennedy, A.C. (1967b) Haemodialysis in the treatment of severe barbiturate intoxication. Trans. Eur. Dialysis Transplant Ass. 4, 293.

ShUBIN, H. \& WeIL, M.H. (1965) The mechanism of shock following suicidal doses of barbiturates, narcotics, and tranquiliser drugs, with observations on the effects of treatment. Amer. J. Med. 38, 853.

Solberg, C.O. (1961) Phenelzine intoxication. J. Amer. med. Ass. 177, 572.

STRICKLER, J.C. (1966) Forced diuresis in the management of barbiturate intoxication. Clin. Pharmac. Ther. 6, 693.

WINSOR, T. (1959) Mephentermine sulfate for treatment of arterial hypotension. J. Amer. med. Ass. 169, 1742. 